\title{
Producer Control in the New Zealand Meat Industry in the 1940s/1950s
}

\author{
DAVID HALL
}

\begin{abstract}
The New Zealand Meat Producers' Export Control Board, set up in the 1920s, implemented a policy of producer control of meat processing facilities to maximise producers' income by restricting foreign investment in New Zealand. Meat Board members were not chosen directly by producers but indirectly through an electoral college system. Previous authors have suggested that that system isolated Board members from producer interests. This paper concludes that in the period after World War II the Board, led by an intransigent chairman, had indeed become detached from producers and its policy of producer control operated against producer interests.
\end{abstract}

\section{Introduction}

From the 1920s, economic uncertainties for New Zealand's dominant exports of agricultural and pastoral products encouraged governments to set up a series of producer organisations. The objective was to organise better exports for the benefit of the whole of New Zealand and to provide better security of income for the primary producers themselves. Export of meat was one of the key export sectors, and in 1921 meat producers and the government agreed that there should be a Meat Producers Export Control Board. ${ }^{1}$ This was because low overseas prices together with increases in farming and transport costs had meant poor returns for producers. It was felt that promotion of "public economic welfare" would be best achieved by a board of control. ${ }^{2}$ From the start the board considered that its prime objective should be to control the whole of New Zealand's exported meat so that it yielded the highest net return to the producer. ${ }^{3}$ To achieve that objective, the board saw itself as an advocate for meat producers, acting as a lobby group towards the New Zealand Government and doing its best to be involved in all key governmental discussions on issues affecting the meat industry. Bruce Curtis describes the Meat Board's role as "the champion of farmers." 4 That role was helped by governments using the board as an advisory body. In striving for the highest net return, the board interpreted that it should be active also in reducing costs both within and external to New Zealand, such as transport costs including shipping. Operations of the board and its administrative costs were met from a levy charged on all exported meat together with profits from the World War I commandeer of New Zealand's meat by Britain.

The board controlled shipment of meat by acting as an agent for the producers, thereby providing a single, strong, body for negotiating shipping rates, and the board was successful in achieving significant reductions. ${ }^{5}$ The board played an important role in ensuring the quality of meat for export by controlling arrangements for grading, handling, pooling, and storage of meat as well as through inspection and hygiene control at places such as abattoirs. At first, the board dealt only with sheep meat, but its coverage was expanded gradually to include beef, canned and processed meat, game meat, and fish. One formal function of the board was to control export through the issue of export licences; export without the approval of the board was prohibited. Curtis reports that that role was included to maintain producers' control of the processing facilities in New Zealand. ${ }^{6}$ Following the upheaval of the "commandeer" of meat for Britain during World War I, there was an increasing threat that freezing works would be taken over by overseas meat processing companies (Vesteys, Swift, Borthwicks), who were well established globally through their connections with the US, British, Argentinian and

Journal of New Zealand Studies NS25 (2017), 72-87 
Australian meat industries. Curtis describes how those companies operated to the detriment of farmers, especially in the USA and Argentina. ${ }^{7}$ Until World War I, New Zealand freezing factories were farmer-owned, and that was thought to maximise the return to farmers. The Meat Board was set up partly to defend that arrangement, and at the start of 1940 most freezing companies remained New Zealand-owned. Fear of dominance by overseas companies remained twenty years after formation of the Meat Board: Mr K. W. J. Hall summarised farmers' fears when he told the North Canterbury executive of the Farmers Union in 1943 that he should be sorry if any of those [overseas] companies got a hold here. They would be working for themselves and not for us. It is their single aim to get cheap meat into the United Kingdom market. We know where we are with our own firms. ${ }^{8}$

During World War II, the government's internal marketing department took over the marketing of meat when Britain placed bulk contracts for purchasing the whole of New Zealand's exportable surplus. ${ }^{9}$ At that time, the government was also determined to prevent inflation, and introduced a price stabilisation scheme. As Britain increased the prices for meat, the New Zealand Government put the increases into a meat industry reserve account, whilst keeping payments to farmers at the level of prices in place in December $1942 .{ }^{10}$ By 1949 , that reserve had reached $£ 29$ million (more than NZ $\$ 2$ billion in 2017 values); it could be spent by the Meat Board only with the agreement of the minister of agriculture.

The first Meat Board comprised five representatives of meat producers and two representatives of the government. Provision was also made for a representative chosen by stock and station agents, but the first representative proposed by the agents was overly critical of the board and rejected by the government; the agents refused to propose an alternative. ${ }^{11}$ Representatives of the producers were elected not directly by producers but by an electoral college of, at first, 6 members and, later, 25 members, the college members being elected on a district by district basis by producers. The electoral college system was partly a consequence of the way in which the negotiations to confirm details of the board had been carried out; rather than negotiations in a full meeting of 140 representatives of producers a smaller group had been selected. ${ }^{12}$ Before it merged with other farmers' organisations to become Federated Farmers at the end of 1945, the Farmers' Union wanted direct elections for board members, but lacked support from the board and the government. ${ }^{13}$ Farmers were especially critical at that time of the "paucity of information issued by the board and the secretive nature of its deliberations." 14 That plea for a change in election of board members surfaced regularly but was always successfully defended by the board. ${ }^{15}$ The board supported producer control but kept itself distant from producers.

Bartley reports that the board's first chairman claimed that the electoral-college system meant that board members were chosen by those taking the national interest into account rather than regional issues. ${ }^{16}$ Bartley also suggests that because the board would have to make decisions which compromised farmer interests in favour of other sectors of the industry, a degree of isolation from direct control by all farmers was thought necessary. ${ }^{17}$ He suggests that the decision to use the electoral-college system rather than direct elections isolated the board from producers and reduced accountability. ${ }^{18}$ According to Bartley the board became "an old boys club" in which members were frequently returned unopposed, with only small percentages of producers actually taking part in elections for the electoral college. ${ }^{19}$ Phillip Herman agrees with Bartley, claiming that the Electoral College arrangement led to "accountability ... far removed from ... those whose interests that system had been designed to serve." 20

This paper investigates the period after World War II, when the board was at its most powerful through having access to the considerable resources of the Reserve and a guaranteed market through continuance of wartime bulk purchase by Britain, asking whether the board 
had become detached from producers, and whether its policy of producer control no longer operated in favour of producers.

\section{Meat Board Relations with Producers in the 1940s}

In September 1945 only 46 per cent of farmers voted in the Electoral College elections, and that led the Meat Board to complain about the "apathetic attitude of farmers." If farmers did not take "a more active role in conducting their own affairs that privilege might be taken away from them." 21 But Federated Farmers claimed that it was the electoral arrangements that led to that apathy:

the college system protects a gross betrayal of the producers' interests. The chain of responsibility to the individual farmer-voter is so long and so involved, little can be done to sheet home the responsibilities of Board members. The archaic, cumbersome and undemocratic college system gives all the protection needed in just such a case. The Board can ... gracefully climb out of the trouble which should beset it. It must, therefore, be happy in the isolation of its sheltered position, as immune from direct criticism. $^{22}$

How producer control worked out in practice for the Meat Board is illustrated by the debate during the 1940s and 1950s over ownership of freezing works. The Meat Board and Federated Farmers policy was that ownership should be by New Zealand farmers in cooperative organisations. At the start of 1940 about one-quarter of freezing factories were farmers' cooperatives, half were proprietary companies with shares held by farmers, and one-quarter were owned by overseas companies (Table 1). But many New Zealand-owned companies had contractual arrangements with specific overseas companies as buyers, giving the overseas companies strong influence (Table 1). Curtis concludes that the board's policy of resisting overseas control of freezing companies made New Zealand-owned companies subcontractors to the overseas companies. ${ }^{23}$ Through those arrangements the overseas companies controlled, at the end of World War II, 80 per cent of meat exports from the North Island and about half the exports from the South Island. ${ }^{24}$

The board and Federated Farmers justified attempts to stop overseas ownership of freezing factories growing through the mantra of "producer control." Dai Hayward describes that policy at the moment of the formation of the board in the 1920s thus:

Overseas meat interests have, rightly or wrongly, been regarded as the bogey-men of the export meat industry. It was always accepted that competition was necessary and that to a degree, this was supplied by overseas companies. However, the Board feared, especially during its early days, that an increase of overseas control would lead to a monopoly and the essential competition would thus disappear.... In January1923 it passed this rather dramatic resolution: "That this Board will look with an unfriendly eye upon: (a) the purchase by overseas interests of any Freezing works in New Zealand, (b) the acquiring of any interest in New Zealand Freezing works by overseas interests, and (c) the erection of new Freezing works in New Zealand by overseas interests. $" 25$ 
Table 1: Ownership of New Zealand Freezing Works at the Start of $1940^{26}$

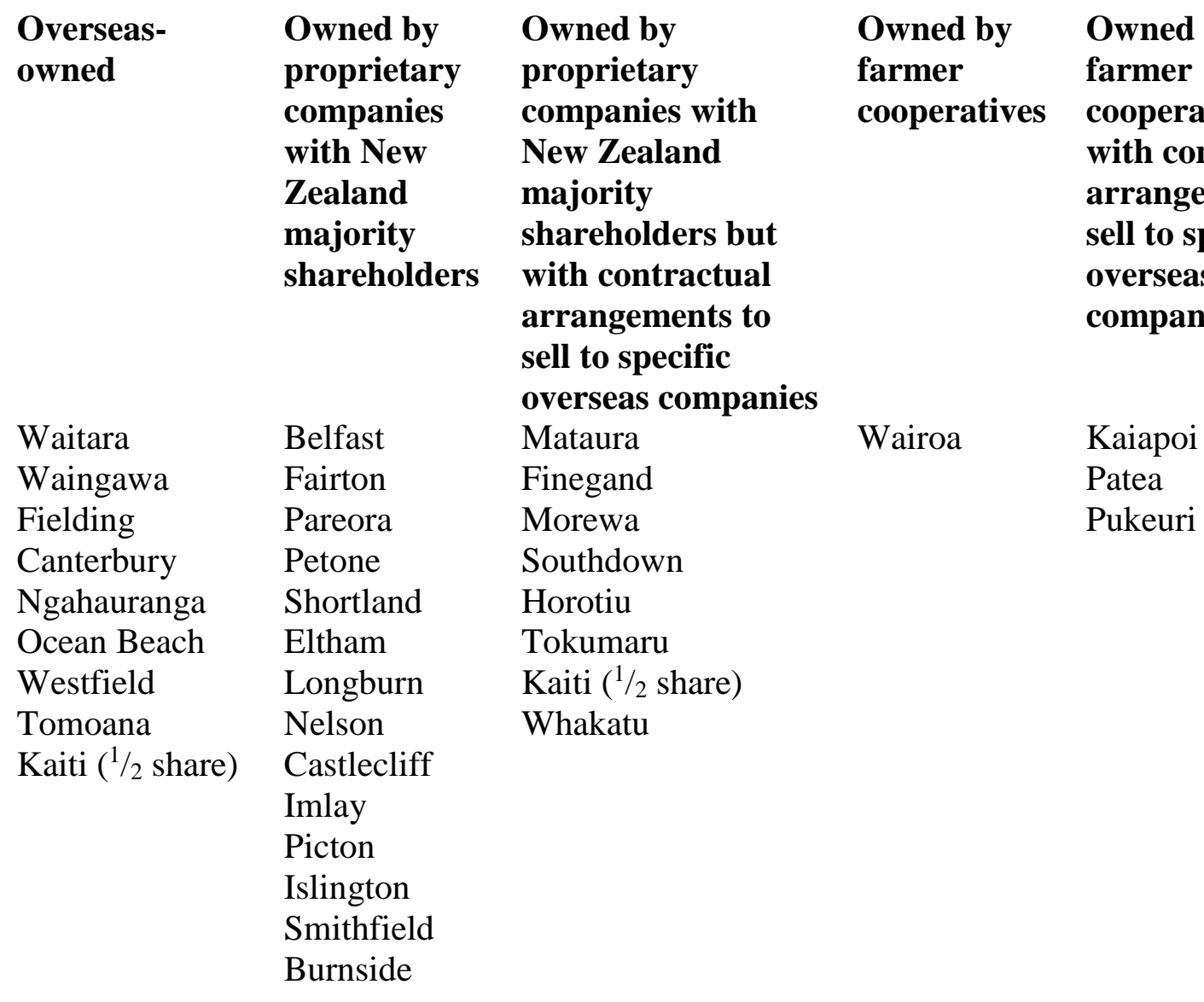

Towards the end of, and just after, World War II, overseas ownership of freezing works was increasing. Up to 1944, the freezing works at Tokomaru Bay had been a cooperative venture amongst local farmers, but the works were sold in 1944 to the overseas company Borthwick and Sons. Also in 1944, the Ocean Bay works in Southland was taken over (from a New Zealander living in London) by an overseas company, much to the dismay of the Farmers Union. ${ }^{27}$ The Union criticised the Meat Board, which it said had been "created to see that [producer] cooperative works continued," and should have had the "forethought" to prevent the sale. ${ }^{28}$ Board members were criticised for talking about cooperative ownership of freezing works whilst allowing the "sale of farmers" works to overseas interests." The article wanted to "dispose" of the board members, but claimed that that was not possible because through the electoral-college system members were selected to represent a district and not because of their views on overseas sales. The article saw this as giving the board members "immunity from chastisement."

Two months later, the farming magazine Straight Furrow gave space for one of the farmers who had sold the Tokomaru works to explain the situation. ${ }^{29}$ He claimed that the works had been run at a loss for years because there was insufficient stock in the area; that loss had been subsidised by charging high prices at another local works at Kaiti. By selling Tokomaru the charges to farmers at Kaiti would be less. Also, there had been fears that the works at Tokomaru would close altogether, inconveniencing those local farmers who had used it. The farmer reported that "Expressions of opinion" by local farmers on the sale "have all been 
favourable." Farmers did not support the board policy of producer control when their incomes were threatened.

In February 1945, the prime minister favoured renewing the lease of the freezing works at Ngahauranga for the American company Swift. The new lease was to be without the condition of the previous lease that prevented Swift from acquiring shares in the Wellington Meat Exporters Company (WMEC), the actual owner of the works. The board met the prime minister making it clear that it opposed foreign ownership and favoured ownership by New Zealand producers. ${ }^{30}$ The board's power in approving licences for meat exporters enabled it to confirm its policy of producer control by refusing to approve a new licence for Swift. The board "decided to approach the farmers" organizations to see whether they desire to offer an alternative proposition along the lines of the works being acquired by farmers." Specifically, the board wanted farmers local to the freezing works to invest in a farmers' cooperative to take over the works. ${ }^{31}$

At its meeting in May 1945, the board could report that there was a desire to form a farmers' cooperative, and the board proposed that two-thirds of the initial capital be provided from the Meat Reserve fund. But legal advice was that the conditions imposed on the use of those funds meant members of the new company had to secure guarantees of an "adequate supply of fat-stock to permit economical operation" for not less than ten years. ${ }^{32}$ In July 1945 , the general manager of the board reported that farmers were "not generally favourable to signing any document" giving such a guarantee because there was uncertainty over both the cost of reconditioning the works and future ownership of the works. ${ }^{33}$ In August 1945, the Farmers' Union confirmed that, though it favoured the cooperative system of ownership, the uncertainty about the value of the works and the cost of restoration made it impossible to obtain the essential guarantee of fat-stock. ${ }^{34}$ The Meat Board general manager gave his interpretation of why a guarantee by farmers had not been secured:

Unfortunately, in the southern part of the North Island there were many graveyards of farmers' money which had been put into producer-owned freezing works in the past and little enthusiasm could be stimulated in the new proposals. ${ }^{35}$

The board decided to ask the government to allow the board to use the meat reserve to purchase the works "if there is no other way to prevent the ownership from passing to an overseas firm." 36 The government refused, and decided that it would lease the company to Swift as planned, thereby allowing Swift to purchase the WMEC and acquire ownership of the works. The government had faced diplomatic pressure from the USA in support of Swift and had to keep a careful balance between New Zealand export interests and the need for American support during the trade negotiations that followed World War II. ${ }^{37}$ The board recorded its objection but had to accept the situation, partly fearing that its right of approving licences would be taken over by the government. ${ }^{38}$

What emerges from the Ngahauranga case is that farmers recognised that producer control carried with it producer risk; individual farmers rejected producer control if it carried financial risk for themselves, they preferred to see the Meat Board or government, or even an overseas-owned company, taking that risk.

\section{The Freezing Industry in Southland}

A specific case study that demonstrates how producer control worked out for the Meat Board, Federated Farmers, the government and farmers, is the introduction of much-needed processing facilities in Southland. ${ }^{39}$ That introduction was delayed for a decade mainly because the Meat Board insisted on a policy of producer control even though that policy operated against the wishes of Southland producers and was to their detriment. It serves well as a case study because Clive Lind, using Alliance Freezing Company papers together with interviews with those 
associated with the Company, has described developments from the company's point of view during the long delay. This paper focuses on developments as seen by the Meat Board, Federated Farmers (at national and provincial levels) and the government. Lessons learnt are that a mantra such as producer control can become too rigid, especially when a strong, opinionated personality leads a board that had become detached from farmers; the board may actually act against producer interests.

There had been long-term dissatisfaction with the meat processing facilities in Southland. Farmers claimed that from 1938 "congestion and the lack of facilities was extremely difficult and chaotic." 40 Two processing and marketing companies operated in Southland, the Southland Frozen Meat Company (SFMC) and the Ocean Beach Freezing Company, the former being by far the most influential. Both were proprietary companies rather than cooperatives, SFMC being owned mainly by farmers and Ocean Beach by a New Zealander (Arthur Sims) who was living in London. The companies operated joint agreements to control their throughput in the companies' interests rather than farmers. ${ }^{41}$ When Mr K. W. J. Hall addressed the North Canterbury executive of the Farmers Union in 1943 warning of the influence of overseas companies, he was asked if that meant New Zealand companies in the South Island were working for farmers. He replied:

No, I wouldn't go as far as that. But while their shareholders include local farmers I think they tend to be more sympathetic to our interests.

Facilities in Southland compared unfavourably with those in other parts of New Zealand (Table 2): the ratio of annual killings to daily capacity being double that of Auckland and 50 per cent more than that in Hawke's Bay. Also, in Southland, the killings were compressed into a shorter killing season. Fat-stock producers had to adopt farming practices to fit in with the timetables set unilaterally by the companies, instead of the companies setting the timetables to fit in with good farming practice. A group of Southland farmers decided that they should invest in a new works under their own control.

\section{Table 2: Killing Capacities and Annual Killings for Auckland, Hawke's Bay and Southland in 1950}

\section{District}

Auckland

Hawke's Bay

Southland

Daily Capacity for killings
47,000
26,000
25,000

\author{
Annual Killings \\ $2,322,994$ \\ $1,715,598$ \\ $2,309,601$
}

Gilbert Grigg, the Meat Board chairman, and other representatives of the board, met the disgruntled farmers in Invercargill to discuss the proposal for a new works, expected to be run "either by a farmer cooperative company or by a proprietary company with capital provided by farmers on a 50-50 basis." "42 At that March 1946 meeting, Grigg suggested the formation of a company in which shares would be held by farmers. Another Meat Board member stated that the type of company to operate the works should be left entirely for the farmer to decide ${ }^{43}$ But farmers were warned against a purely farmers' company. ${ }^{44}$ Lind reports that the Meat Board representatives warned the farmers that the proposed cooperative works would have "to run the gauntlet of competition." 45 The President of Southland Federated Farmers reported in 1952 that the advice given by the Meat Board at that meeting in 1945 was:

not to attempt to run a works as a purely farmers' company, but to do so with a strong partner. Otherwise, in bad times ... there would be nobody to support the works, as there would be no important buyer with any financial reason for doing so. It was 
emphasised that a buying partner with a financial interest in the works would be bound to protect the capital invested by supporting the works in all circumstances. ${ }^{46}$

In August 1946, the board received a letter from Southland Federated Farmers stating that the Federation had approved a proprietary company to apply for a licence to set up a new freezing works in Southland. Also, that Borthwick and Sons and the Canterbury Frozen Meat Company had been asked "if they would be prepared, under certain conditions, to apply for a license for the erection of a new works in the district." 47 In November 1946, Southland Federated Farmers asked whether or not the Meat Board would recommend the granting of a licence. The board's response was that it would not "give a decision until complete information regarding ownership was available." 48

In January 1947, the Meat Board sought stronger control over the sale of freezing works throughout New Zealand, and requested that the government amend the Meat Act so that any freezing company wishing to sell works in New Zealand had to obtain the board's permission. ${ }^{49}$ The final version of the amendment was that permission had to be obtained either from the minister or from the Meat Board acting with the authority of the minister; the government remained adamant that it would not let the board have a veto over sales of freezing works. ${ }^{50}$

At its August 1947 meeting, the board received a "lengthy submission from Southland Federated Farmers in support of a request for a new licence," and the board agreed "to support an application for a new licence by applicants approved by the board." 51 A Southland SheepFarmers Company had been formed to set up new works. The board representatives had anticipated that "the strong partner, someone established in the meat industry with practical know-how of operations of a works," would be an existing company such as the SFMC or the Canterbury Freezing Company. But Southland farmers had investigated those possibilities and been rebuffed. ${ }^{52}$ Three months later, the board was taken aback when it was read a letter from the minister noting that the Southland Sheep-Farmers Company intended to join in a 50-50 partnership with the overseas-owned W. \& R. Fletcher (NZ) Ltd to form the Alliance Freezing Company (Southland) Ltd, with the intention to erect a new slaughterhouse. ${ }^{53}$ That was counter to the expectations of the board and would introduce the foreign ownership that the board had sought to avoid, Fletcher was owned by the major UK company Vesteys. The President of Southland Federated Farmers justified the decision to join forces with Fletcher; farmers would have a

strong partner with a wide and lengthy experience in the erection and operation of freezing works, and processing and production standards of both the meat and the byproducts which are the highest in the Dominion. Also with an unrivalled worldwide selling organisation. We also have a guaranteed throughput sufficient to assure the financial success of the company. ${ }^{54}$

The minister asked the board to recommend granting a licence and erecting new works but the board refused, telling the minister that Fletchers already had "the largest share of New Zealand's Meat Export Trade.... It was not in the interest of Producers for this concern to obtain any greater hold." ${ }^{\prime 55}$ But the board refused to give reasons for the rejection to those representing Alliance. The board considered that keeping to a national principle of producer control outweighed the interests of the local producers in solving their difficulties. Federated Farmers, nationally, shared the doubts over the proposed arrangement with Fletchers; for instance, farmers would get only "what was left after the proprietary company had taken its share," and farmers might sell their shares, thereby reducing producer control of the venture. ${ }^{56}$

In March 1948, Grigg and his general manager visited Federated Farmers in Southland to explore possible compromises, but hurriedly had to issue a press notice to correct "the incorrect impression in the minds of many farmers" that the board supported the proposal for 
new works involving Fletchers. The board reiterated that "there shall be no increase in overseas ownership or control of freezing works in New Zealand." 57 At its June 1948 meeting, the Meat Board met those representing Alliance, including a representative from Fletchers, and agreed to consider a license at its July meeting. ${ }^{58}$ During the July meeting, the board, with John (later Sir John) Ormond as acting chairman, prevaricated, deciding "to seek evidence from interested parties" and hear "oral amplification of written submissions" at its August meeting. ${ }^{59}$ In October, the board considered again a request from the minister that the board recommend granting a licence to Alliance; the board again rejected the application, and also refused to tell the minister why the licence was rejected.

In April 1949, the dominion president of Federated Farmers gave his opinion on what should be done in Southland, and demonstrated the uncertainty within Federated Farmers over recognising the obvious need in Southland but not wanting to go against the policy of restricting foreign ownership. He said that it was essential that a "new element" should be introduced in Southland but "the form of the new element ... is a matter between Southland producers, the Meat Board and the government ... but something must be done. ${ }^{60}$ In August 1949, the board, caught between wanting to see a farmers-owned freezing works but fearing that meant overseas involvement, came up with the compromise that the board support the Alliance farmers in purchasing one of the existing SFMC works, that at Mataura. ${ }^{61}$ But farmers still sought their own new works, partly because a new works would incorporate modern technology. The frustrated farmers petitioned Parliament seeking an amendment to the Meat Act that would remove the Meat Board's veto over the ministerial approval of export licences to new organisations. The petition pointed out that increasing the facilities in Southland was "of paramount importance to assist the Dominion of New Zealand in honouring its obligation to increase supplies to the United Kingdom," an obligation New Zealand failed to honour. ${ }^{62}$ Parliament set up a committee to investigate the circumstances, and that committee criticised the Meat Board for refusing to give the minister reasons why it refused Alliance a license; the board, it said, should not make the minister "subservient to the Board." 63 The committee chairman suggested the time had come when there should be a different arrangement for electing Meat Board members so that there would be a "closer bond between the board and producers." But the committee made no recommendation on the request for a license for Alliance, and supported the policy of preventing any extension of overseas ownership. The Minister of Finance expressed the dilemma on overseas ownership, saying it was a "menace" for overseas companies to have the major controlling interest but "it was well that outsiders should assist farmers with their skill and knowledge." 64

During the general election campaign of 1949, Southland farmers secured a statement from the leader of the National Party, Sidney Holland, that:

If the National Party becomes the Government at the approaching election, it will be prepared, at the conclusion of the coming killing season, to set up a commission of inquiry into the question of the establishment of an additional freezing works in Southland, it being understood, as was agreed when I met the deputation in Invercargill, that the finding of the proposed tribunal would be accepted as final. ${ }^{65}$

In November 1949, the National Party was elected to government, replacing the Labour Government of the previous 14 years. The Southland section of Federated Farmers went against the prevarication among Federated Farmers national leaders and stated unequivocally that a license should be granted immediately to Alliance. ${ }^{66}$ The new government kept Holland's commitment, and decided that the question of ownership of Freezing works in Southland was of sufficient interest nationally that a Royal Commission should investigate "the desirability of establishing an additional meat export slaughterhouse in Southland". ${ }^{67}$ 


\section{The Influence of John Ormond}

Lind reports that Alliance were dealing with John Ormond, who "usually got what he wanted." 68 Ormond was a determined advocate of the Meat Board policy on ownership of freezing plants, and from the late 1940s the Meat Board approach was a reflection of Ormond's intransigent nature. Ormond grew up in a family whose position resembled the landed gentry in Britain. His family had become established in New Zealand in the middle of the nineteenth century, and his grandfather played a major role in the development of the Hawke's Bay region, representing the region in the House of Representatives and being appointed to the Legislative Council on retirement from the House. Ormond at first tried to follow his grandfather into politics, and during the 1930s was a leading proponent of the New Zealand Legion, a radical, extreme right-wing party, in which he hoped to play a leading role. ${ }^{69}$ When it became clear that the Legion would not grow into a significant party, Ormond stood as a National candidate for election to Parliament in 1935. The local press reported that "round the name of Ormond there is an allure that will win hundreds of votes in a farming constituency." ${ }^{70}$ His approach at the time demonstrated his intransigent manner. His election posters told voters that "he is convinced that efficient government necessitates more independent expression of opinion by members." He supported National, but "will not necessarily vote with the party but with discretion." 71 Ormond was unsuccessful in gaining election, partly because he could not commit himself to a political party in which he did not have a dominant role. Becoming a member of the Meat Board allowed him to play a dominant role unencumbered by the threat of deselection.

Ormond first became a member of the Meat Board in 1933-34 and resigned to fight overseas during World War II, rejoining the board in 1944 after returning to New Zealand following an injury during the battle for Crete. He became deputy chairman of the board in the late 1940s and chairman from 1951 until 1972. One justification offered to him for the invitation to be the chairman was "You are one of the offspring of one of the most honoured families in New Zealand." 72 His role as Meat Board chairman gave him far more influence over New Zealand governments than he would have had as a member of parliament; certainly, at least, Ormond saw it that way. At one meeting he told Robert Muldoon, then finance minister, "sit down, Muldoon, sit down. You do not control this country, Jack Acland [chairman of the Wool Board and Ormond's brother-in-law] and I control this country.",73 Ormond would have disagreed vehemently with the parliamentary committee's comment in 1949 that the Meat Board should not make the minister subservient to the board.

Ormond established a strong working relationship with Keith Holyoake, who was minister of agriculture in the 1950s and prime minister in the 1960s; both shared mutual respect, though disagreeing on many occasions. ${ }^{74}$ Ormond also built up a strong relationship with Fintan Patrick Walsh, a key figure in labour relations in the 1940s and 1950s through his control of the Federation of Labour. Ormond and Walsh did not share political views but had common interests through being mavericks in their respective fields, preferring to settle matters over drinks rather than at formal meetings. According to his biographer, "Walsh got on particularly well with the hard-drinking Ormond."75 According to Ormond's biographer, "despite their differing roles and background, the two men soon built up a rapport.",76

Ormond's maverick nature secured his long-term support from farmers, because he was a strong well-publicised leader who stood up to government in both New Zealand and Britain. Ormond's brusque, outspoken manner and determination made him effective with both the media and politicians. He was not skilled at reasoned debate, but was an early example of politicians who push their argument through the media rather than statutory bodies. ${ }^{77}$ Barry Gustafson's comments on Robert Muldoon were appropriate for Ormond: he "asserted rather than explained the positions he took," and "he speaks in newspaper headlines."78 Peter Tait, in his biography of Ormond, reports that Ormond "fully realised the value as a farmer politician 
of keeping his name to the fore" and he "did his best to ensure that he was not only available to the press, but that he was good copy."79 One prime example of his approach was that in 1951, just before becoming board chairman, he said in an interview with the Press Association that "it's time we twisted the lion's tail," referring to upcoming price negotiations with Britain. Many were horrified at the disrespect shown to Britain, but when the New Zealand delegation, led by Holyoake, returned from the price negotiations with New Zealand having achieved a 12 per cent increase, Ormond was given the credit. That episode cemented Ormond's reputation amongst rank and file farmers as someone who spoke in their language. From 1950, the Alliance farmers were faced with a powerful and intransigent opponent.

\section{Report of the Royal Commission}

The Royal Commission reported in 1951, and found the concern of Southland farmers to be fully justified:

The detailed evidence of the large number of Southland fat-stock producers was not seriously shaken by close and competent cross-examination; nor was it traversed by evidence called on behalf of the Meat Board or of the freezing-works companies. The Commission is satisfied that most of the farmers of the district sincerely and honestly believe that the freezing-works companies have run their businesses solely in their own interests, with the result that the fat-stock producers have had to adopt farming practices to fit in with the timetables set unilaterally by the companies, instead of the companies setting the timetables to fit in with good farming practice.

There are, of course, two sides to this question, but if the companies had made an endeavour to meet the executive of Federated Farmers with a view to minimizing any problems which could not be adjusted or resolved wholly, the differences, misunderstandings, and ill feeling ... might not have developed to a state which could fairly be described as "tragic." The blame for allowing the breach between the two interests to develop in the way it has must, in the Commission's opinion, rest upon the companies. ${ }^{80}$

The commission had no doubt that the projected fat lamb production in Southland needed new works. Export killings had doubled in the previous 15 years (Table 3); the commission expected that rate of increase to continue. ${ }^{81}$ Ten per cent of the killings were already taking place by transporting lambs outside Southland because of the lack of local facilities. The commission accepted that the actions and persistence of the farmers in pressing for a new company were fully justified. ${ }^{82}$ The commission decided that "Federated Farmers ... is one of the most powerful, influential and useful organisations in the country" and is "able to afford strong protection against any scheme or policy which might prevent a farmer reaping the full reward of his labour." 83 The board had always claimed that protection of producers had been its major objective; the commission had decided that Federated Farmers was the more effective of the two organisations in achieving that objective. The commission's findings were a further indication that the board had become divorced from producers and at times acted against the interests of producers. 
Table 3: Total Killings of Sheep and Lambs in Southland, 1935-1950

$\begin{array}{ll}\text { Year } & \begin{array}{l}\text { Total Killings of Sheep and } \\ \text { Lambs }\end{array} \\ 1935 & 1,185,733 \\ 1936 & 1,211,303 \\ 1937 & 1,132,361 \\ 1938 & 1,300,314 \\ 1939 & 1,392,248 \\ 1940 & 1,602,550 \\ 1941 & 1,692,105 \\ 1942 & 1,709,158 \\ 1943 & 1,635,630 \\ 1944 & 1,612,922 \\ 1945 & 1,717,060 \\ 1946 & 1,837,790 \\ 1947 & 1,952,147 \\ 1948 & 2,024,464 \\ 1949 & 2,117,810 \\ 1950 & 2,309,601\end{array}$

The specific criticism of the board by the Royal Commission was that its policy of refusing a licence for a company in which any overseas concern had a substantial interest "may operate against the public interest." 84 The board was also criticised for not explaining to Alliance why the board refused to grant a licence. The Meat Board's weak responses to the commission's questioning is demonstrated by Grigg's responses. He had told the commission that "the fact that Fletchers was a partner in the company was not the reason for refusing the application." Earlier, however, he had admitted that granting a licence in which a half share was to be held by Fletchers would be contrary to the board's policy. ${ }^{85}$ The board's position was further weakened because, in the period leading up to the commission, the board, to procure a meat distribution company in Britain, went into minority partnership with the overseas meat companies that it was opposing, in terms of their increasing ownership of freezing works in New Zealand. The board was criticised by Federated Farmers because the arrangement would not give producers' control of meat distribution in what was, by far, New Zealand's main export market. ${ }^{86}$

The Royal Commission considered that "a statutory body like the Board constituted to carry out its functions in the public interest should not adopt a policy which may result in unfair discrimination, unless such a policy is specifically authorised by statute." The commission recognised that the board's policy was because of the "long-standing fear of New Zealand farmers of exploitation by powerful overseas companies." Nonetheless, the Meat Export Control Act of 1921 and the Meat Act of 1939 had given "great protection to the fat stock producer." Continued prejudice against the expansion of British meat companies in New Zealand "might not be in the best interests of Commonwealth relations." The commission recommended that the Meat Act "be amended to define those matters which the board must consider before making a recommendation on a new licence." 87 


\section{Continuing Attempts to Prevent Alliance from Building a New Freezing Works}

At its September 1951 meeting, the first with Ormond as chairman, the board "completely and unreservedly accepted the opinion of the Royal Commission," but postponed a decision on the license for Alliance. ${ }^{88}$ One month later, the board decided that it would continue to refuse to recommend a licence for Alliance. But the board would:

negotiate immediately with the farmers of Southland for the purpose of facilitating the erection of such a works and, subject to the approval of the Government, make available for that purpose substantial financial assets from the Meat Industry Reserve Account. ${ }^{89}$

Straight Furrow warned that "if the shareholders of the Alliance company did not agree with such an idea en bloc the board would probably negotiate with those who were prepared to enter the new scheme and provide a reasonable amount of capital." ${ }^{90}$ Ormond and his board began manoeuvring to outflank the Alliance group of farmers.

Ormond gave a formal response to the commission's findings to the Federated Farmers meat and wool section two months after the commission had reported:

The policy which my Board has recommended to the Government in connection with the proposed Southland works is that this works, and all other works[,] ... shall be a farmer-owned, preferably cooperative, processing works.... Such a policy eliminates difficulties of deciding between overseas and New Zealand interests in the freezing industry and ensures that there is no interference with any trading operations in New Zealand.... The Board was concerned that decisions had been made in the past that were merely expedient. It would endeavour to see that this did not happen again and to this end, laid down a definite principle which could be accepted as policy and precedent for the future. We can see no other way of dealing with the ownership of what are really monopolies ... and at the same time ensuring that there is open and fair competition. We trust that farmers will give us their wholehearted support and that this policy and our action will be endorsed by the Government. ${ }^{91}$

Following the damning, for the Meat Board, conclusions of the Royal Commission, the board had to accept the need for a new works, but, without informing Alliance farmers, started consultations with the minority of Southland farmers outside the Alliance group on forming a "farmer-owned, preferably cooperative" organisation supported by a loan of $£ 2.5$ million at 1 per cent interest from the meat industry reserve account. The government agreed that the Meat Board should go ahead and canvass the non-Alliance Southland farmers, setting a deadline of 31 March 1952 for agreement to be reached that the farmers would contribute sufficient capital in support of the new works. ${ }^{92}$ The Southland Federated Farmers president pointed out that "a purely farmers' company is contrary to the advice given by the Meat Board itself in $1946 \ldots$. Who is going to supply a purely producers' concern with the technical and administrative skills needed to operate the complicated business of a freezing works in these difficult times?." ${ }^{93} \mathrm{He}$ pointed out also that "the people conducting the canvass have not approached Federated Farmers [in Southland]. They have gone behind our backs to a very small minority." 94 The minister for agriculture, Keith Holyoake, reported to the Meat Board that the government "had grave doubts about spending producer funds" on a farmer-controlled works given the past history of such ventures. ${ }^{95}$

Attempts to gain support for the new company from Southland farmers other than those committed to Alliance continued through 1952, with the government extending the original deadline. But, by November 1952, the government decided that the conditions had not been met and a licence should be given to Alliance. In the government's view, the company put 
together by the Meat Board should go into liquidation. It had only reached the target for subscriptions to shareholding by a latecomer from outside Southland agreeing to subscribe to nearly half the necessary shares provided his shares were "disposed of" within six months. But the Meat Board (Ormond?), not wanting to admit defeat, once again refused to recommend a license for Alliance, and asked that Alliance and the board's favoured company should "get together and evolve a mutually satisfactory basis" for a new works. ${ }^{96}$ Holyoake called a meeting of the Meat Board and the two companies "in an endeavour to secure some agreement." 97 Federated Farmers nationally continued in its weak position of sitting on the fence-supporting the policy of not wanting to see overseas ownership increased, but opting not to comment on whether a license for Alliance should be agreed. It distributed a note seeking provinces to support the policy of no increased overseas ownership; the Southland province objected, claiming that the contents of the note were misleading and not a correct statement of facts. ${ }^{98}$

Three years after the Royal Commission had reported, the board still opposed granting a licence to Alliance. ${ }^{99}$ But Alliance refused to give in, and the board had to resign itself to supporting Alliance and accepted that the new works should be run as a farmer shareholder concern by Alliance rather than a cooperative. Dai Hayward, in his adulatory book celebrating the first fifty years of the board, reports this acceptance as the board finding that "participation by local producers [in a farmers' cooperative] was proving difficult to obtain." 100 He does not mention that it took the board more than a decade to accept that. It was not until the late 1950s that the board accepted the reality, supporting the venture with a loan of $£ 4$ million out of the meat industry reserve account at a low interest rate ( 1 per cent) with the condition that Fletcher withdraw from shared ownership. A face-saving arrangement for the board was achieved: Fletcher withdrew from shared ownership, accepting that that was the only way Alliance could succeed, but Fletcher maintained a close relationship by agreeing to "maintain a buying organisation in Southland and will undertake ... to protect the works volume by killing a minimum of 300,000 head during any season." Ormond later claimed that he had persuaded, over a cigar and whiskey, the head of Vesteys in Britain that Fletcher should withdraw. ${ }^{101}$ The new works was opened (by Ormond!) in March 1960, incorporating "the most modern techniques and developments in meat-killing and exporting" and amply demonstrated that it met a need in Southland. ${ }^{102}$

\section{Conclusion}

The Meat Board's intransigence over ownership of freezing works demonstrates that the board exerted a conservative drag on increasing the efficiency of the New Zealand Meat industry after World War II. The board had been created, and saw itself, as the protector of producersits broadcasted, overriding, policy over many years was "to increase the net return to producers." It had no commitment to aid the rest of the industry, such as brokers, buyers, or freezing companies, even though those were essential for the sale of producers' meat. The board recognised a duty to support those bodies only if they were producer cooperatives. Even if they were proprietary companies with farmer shareholders the board viewed them with suspicion, partly because there was always a threat that shares would be sold to non-producers and, at its worst, overseas interests. The board had adopted producer control as a policy, but it was not in the chairman's nature to review whether that was always in the best interest of producers. Producer control often meant producer financial risk; many farmers struggling to secure sufficient returns to invest in their farms were reluctant to take that risk. Southland farmers were prepared to take financial risk in partnership with Fletcher, but the board opposed that for more than a decade. An independent view was given by the Royal Commission that the board acted against the public interest. The board tried hard to prevent Alliance setting up a new works and only grudgingly accepted that after more than a decade of manoeuvring

Journal of New Zealand Studies NS25 (2017), 72-87 
against the Southland producers. The whole episode justifies the conclusions of Bartley and Herman that the board's accountability was weakened by the electoral system and that lack of accountability could be well exploited by an intransigent chairman immune from chastisement.

\footnotetext{
${ }^{1}$ Dai Hayward, ed., Golden Jubilee: The Story of the First Fifty Years of the New Zealand Meat Producers Board 1922-1972 (Wellington: Universal Printers, 1972), 18.

${ }^{2}$ Meat Export Act, 1921.

${ }^{3}$ Hayward, Golden Jubilee, 190.

${ }^{4}$ B. M. Curtis, "Producers, Processors and Markets: A Study of the Export Meat Industry in New Zealand" (PhD Thesis, University of Canterbury, 1996), 61.

${ }^{5}$ Hayward, Golden Jubilee, 47.

${ }^{6}$ Curtis, "Producers," 24.

${ }^{7}$ Ibid., 41-42.

8 "Meat Companies in Dominion: Outside Influences," Press, Vol. 79, 23 September 1943, 3.

${ }^{9}$ Keith Sinclair, Walter Nash (Auckland: Auckland University Press, 1976), 189.

${ }^{10} \mathrm{Jim}$ McAloon, Judgements of All Kinds (Wellington: Victoria University Press, 2013), 61.

${ }^{11}$ Curtis, "Producers," 62.

12 Hayward, Golden Jubilee, 19.

13 “Ocean Beach Freezing Works Sold Overseas," Straight Furrow, 15 March 1945, 33.

14 "Criticism of Meat Board," Straight Furrow, 15 March 1946, 22.

15 “Electoral College Voting System Criticised," Straight Furrow, 1 July 1954, 34.

${ }^{16}$ C. F. Bartley, "The Accountability of the New Zealand Meat Producers Board to Farmers from 1922-1985" (Masters Thesis, University of Canterbury, 1987), 94.

${ }^{17}$ Ibid., 95.

18 Ibid., 93-95.

${ }^{19}$ Ibid., 110. Hayward says that "about $50 \%$ of those eligible usually cast their vote." (Golden Jubilee, 36).

${ }^{20}$ Phillip Herman, "The Electoral Committee of the New Zealand Meat and Wool Boards," Political Science 26, no. 1 (June 1974): 56.

21 “Apathy of Meat Producers," Straight Furrow, 15 September 1945, 8.

22 "Ngahauranga Shares Zoom in Price," Straight Furrow, 15 June 1946, 11.

${ }^{23}$ Curtis, "Producers," 99.

${ }^{24}$ Ibid., 76.

${ }^{25}$ Hayward, Golden Jubilee, 162.

${ }^{26}$ Curtis, "Producers," Appendix 1.

${ }^{27}$ There was confusion over the ownership of Ocean Beach Freezing. Up to the 1940s it was owned by Arthur Sims, who had lived in New Zealand since he was three and played cricket for New

Zealand. But in the 1940s he lived in London. In actuality, his company, Sims and Company, was owned by Vesteys. The works were transferred to the British Cooperative Wholesale Society; the Meat Board accepted the transfer because the company was already "overseas owned." But the Farmers Union seem not to have accepted that it was not New Zealand owned before the transfer. 28 “Ocean Beach Freezing Works Sold Overseas," Straight Furrow, 15 March 1945, 33. Quotations in the rest of this paragraph are from the same.

29 "Sale of Tokomaru Bay Freezing Works," Straight Furrow, 15 March 1945, 14. Quotations in the rest of this paragraph are from the same.

${ }^{30}$ Meat Board Minute Book 8, 16 February 1945, 289.

${ }^{31}$ Meat Board Minute Book 8, 23 March 1945, 293.

${ }^{32}$ Meat Board Minute Book 8, 15 June 1945, 313.

${ }^{33}$ Meat Board Minute Book 8, 13 July 1945, 321.

${ }^{34}$ Meat Board Minute Book 8, 29 August 1945, 326.

35 "The Fate of Ngahauranga," Straight Furrow, 15 October 1945, 5.

${ }^{36}$ Meat Board Minute Book 8, 14 September 1945, 336.
} 
37 "London or Washington?" Straight Furrow, 15 April 1946, 19.

${ }^{38}$ Meat Board Minute Book 8, 05 October 1945, 344-45.

${ }^{39}$ Clive Lind, A Cut Above: Early History of the Alliance Freezing Company (Southland) Ltd, Alliance Freezing Co. (Invercargill: Southland Frozen Meat Ltd. 1985).

40 "Commission's Probe into Southland Meat Killings," Straight Furrow, 15 September1951, 3.

${ }^{41}$ This emerged during the presentations to the Royal Commission in 1950 on the need for a new facility in Southland. A report, the 'Scott-Mathieson' report, had uncovered "interlocking agreements" but the report had been kept secret. The Commission saw the Report but did not reveal its contents.

${ }^{42}$ Lind, Cut Above, 34.

43 "Review of Farmers' Efforts in the Last Five Years," Straight Furrow, 15 October 1951, 63.

44 "Meat Board Plan," Straight Furrow, 15 January 1952, 6.

${ }^{45}$ Lind, Cut Above, $34-35$.

46 "Issue Not yet Decided: Deep Flaws in All-Farmer Scheme," Straight Furrow, 15 January 1952, 6.

${ }^{47}$ Meat Board Minute Book 8, 28 August 1946, 411.

${ }^{48}$ Meat Board Minute Book 8, 1 November 1946, 428.

${ }^{49}$ Meat Board Minute Book 9, 31 January 1947, 444.

${ }^{50}$ Amendment to the Meat Act, 14 August 1947.

${ }^{51}$ Meat Board Minute Book 9, 27 August 1947, 480.

${ }^{52}$ Lind, Cut Above, 36.

${ }^{53}$ Meat Board Minute Book 9, 6 November 1947, 494.

54 "Issue Not Yet Decided," 6.

${ }^{55}$ Meat Board Minute Book 9, 6 November 1947, 494.

56 "Producer Control of Freezing Works," Straight Furrow, 15 April 1948, 37.

${ }^{57}$ Meat Board Minute Book 9, 5 March 1948, 517.

${ }^{58}$ Meat Board Minute Book 9, 4 June 1948, 540.

${ }^{59}$ Meat Board Minute Book 9, 1 July 1948, 543.

60 "President's Attitude to Meat Works for Southland," Straight Furrow, 16 April 1951, 6.

${ }^{61}$ Meat Board Minute Book 9, 30 August 1949, 623.

62 "The Southland Meat Works Petition," Straight Furrow, 15 October 1949, 7.

63 "House Discusses Freezing Industry," Straight Furrow, 15 November 1949, 17.

64 "House Discusses Freezing Industry," 17.

${ }^{65}$ Meat Board Minute Book 9, 4 August 1950, 711.

66 "Southland is After a New Freezing Works," Straight Furrow, 15 May 1951, 15.

${ }^{67}$ Lind, Cut Above, 51.

${ }^{68}$ Lind, Cut Above, 49.

${ }^{69}$ Peter Tait, In the Chair: The Public Life of Sir John Ormond (Waipukurau: CHB Print, 1989), $17-21$.

70 Ibid., 12.

${ }^{71}$ Election Poster John Ormond, Independent Nationalist, System Id 23466, Museum, Theatre, Gallery (MTG) Hawke's Bay.

${ }^{72}$ Tait, In the Chair, 58.

${ }^{73}$ Mick Calder and Janet Tyson, Meat Acts: The New Zealand Meat Industry 1972-1997 (Wellington: Meat New Zealand, 1999), 11.

${ }^{74}$ Tait suggests that Ormond and Holyoake, through their differing approaches (the former, blunt and outspoken; the latter, believing in consultation and consensus), complemented each other in ways that were beneficial for New Zealand (In the Chair, 43).

${ }^{75}$ Graeme Hunt, Black Prince: The Biography of Fintan Patrick Walsh (Auckland: Penguin Books, 2004), 170-71.

${ }^{76}$ Tait, In the Chair, 54.

${ }^{77}$ Geoffrey Palmer, Reform (Wellington: Victoria University Press, 2013), 711. Former prime minister Sir Geoffrey Palmer claims that media-savvy politicians dominate New Zealand politics in the twenty-first century.

${ }^{78}$ Barry Gustafson, His Way: A Biography of Robert Muldoon (Auckland: Auckland University Press, 2001), 190 and 359.

Journal of New Zealand Studies NS25 (2017), 72-87 
${ }^{79}$ Tait, In the Chair, 57.

${ }^{80}$ Royal Commission appointed to inquire into and report upon the desirability of establishing an additional meat-export slaughterhouse in Southland, 1951.

81 "Commission Says New Freezing Works in Southland is a Necessity," Straight Furrow, 15 October 1951,3

82 "Figures in Southland: Figures Show Terrific Pressure Exerted," Straight Furrow, 15 October 1951, 40.

${ }^{83}$ Inset, Straight Furrow, 15 October 1951, 3.

84 "Meat Board Policy Criticised: May Work Against Public," Straight Furrow, 15 October 1951, 3.

85 "Review of Farmers' Efforts in the Last Five Years," Straight Furrow, 15 October 1951, 63.

86 "Meat Board's Plan for London Outlet: Producer Control Not Guaranteed," Straight Furrow, 16

July 1951,3 .

${ }^{87}$ Royal Commission, paragraphs 24-25.

${ }^{88}$ Meat Board Minute Book 10, 12 September 1951, 806.

${ }^{89}$ Meat Board Minute Book 10, 2 November 1951, 811.

90 "Southland License," Straight Furrow, 15 November 1951, 1.

91 "Statement of Board's Policy," Straight Furrow, 15 December 1951, 5.

92 "Meat Board Plan," Straight Furrow, 15 January 1952, 6.

${ }^{93}$ Ibid.

94 “'Southland's President's Anti-Trust Fight," Straight Furrow, 15 January 1952, 7.

${ }^{95}$ Meat Board Minute Book 10, 21 November 1951, 817.

${ }^{96}$ Royal Commission, paragraphs 40-42.

97 "Freezing License Refused," Straight Furrow, 1 November 1952, 5.

98 "Farmers' Federation Clarifies Policy," Straight Furrow, 1 September 1953, 5.

${ }^{99}$ Meat Board Minute Book 9, 05 August 1954, 1063.

${ }^{100}$ Hayward, Golden Jubilee, 164.

${ }^{101}$ Tait, In the Chair, 80.

${ }^{102}$ Ibid., 164. 